\title{
Sistem Informasi Akademik Kartu Hasil Studi Berbasis Web
}

\author{
Bagus Prasetyo ${ }^{1 *}$ \\ Program Studi Teknik Informatika, Politeknik Gorontalo \\ 60111, ${ }^{3 *}$ email : bagus.mhs15@ti.poligon.ac.id
}

\begin{abstract}
Kampus Politeknik Gorontalo (POLIGON) adalah salah satu Perguruan Tinggi Swasta yang memiliki beberapa program studi unggulan diantaranya, Teknik Hasil Pertanian,Mesin Peralatan Pertanian,Teknik Informatika. Dalam proses pelayanan akademik di Politeknik Gorontalo masih kurang efektif, karena pelayanan kepada mahasiswa belum sepenuhnya menggunakan sistem terintegrasi berbasis online. Dengan permasalahan tersebut maka dibuat aplikasi yang terintegrasi ke semua bagian untuk menunjang pelayanan akademik di Politeknik Gorontalo. Perancangan dan desain sistemnya menggunakan konsep Diagram Alir Data dari proses analisa sampai dengan implementasi sistemnya. Dari hasil percobaan yang dilakukan, sistem berjalan dengan baik dengan data simulasi yang digunakan, sudah terintegrasi ke semua modul (KRS,Absen,Nilai,Kuisioner dan Bimbingan) Siakad. Sistem Informasi Akademik Kartu Hasil Studi Berbasis Web, dikembangkan menggunakan Framework PHP yaitu CodeIgniter dan Mysql untuk pengembangan Sistem Informasi Akademik Kartu Hasil Studi.
\end{abstract}

Kata kunci : Sistem Informasi Akademik,Politeknik Gorontalo, $P H P$, Mys $Q L$

\section{PENDAHULUAN}

Teknologi Informasi merupakan sarana yang sangat penting dan menunjang bagi suatu badan/ instansi/ departemen/ perusahaan baik negeri maupun swasta. Kampus Politeknik Gorontalo atau yang biasa disebut POLIGON merupakan salah satu instansi yang berada di Provinsi Gorontalo yang salah satu tugasnya adalah memberikan pelayanan kepada masyarakat untuk menyiapkan sumber daya manusia (SDM) masa depan bermutu dan berdaya guna. Dalam prosesnya, Politeknik Gorontalo sudah memiliki Sistem Informasi Akademik .

Sistem Informasi Akademik yang berada di Politeknik Gorontalo merupakan suatu sistem yang memberikan informasi laporan keaktifan mahasiswa secara online yang berupa, Monitoring Perkuliahan yang hasil akhirnya adalah Kartu hasil Studi (KHS), Pengurusan Kartu Rencana Studi (KRS) serta Jadwal Matakuliah. Untuk menunjang sistem informasi akademik langkah yang harus diambil adalah mengembangkan Sistem Informasi Akademik dan pengimplementasian di Kampus Politeknik Gorontalo merupakan yang harus dilakukan, salah satu yang masih bisa dikembangkan dalam Sistem Informasi Akademik adalah Monitoring Perkuliahan.

Penelitian yang sudah dilakukan sebelumnya oleh Eton Husin .Amd, membahas tentang "Sistem Informasi Akademik

\author{
Ismail Mohidin $^{2 *}$, Alimuddin Yasin ${ }^{3 *}$ \\ Program Studi Teknik Informatika, Politeknik Gorontalo \\ 60111, ${ }^{2^{*}}$ email : is.mohidin@poligon.ac.id
}

Monitoring Perkuliahan Berbasis Web Di Politeknik Gorontalo", yaitu Sistem akademik yang memungkinkan mahasiswa untuk melihat dan mengolah data perkuliahan, antara lain berupa informasi transkrip nilai dan KHS (Kartu Hasil Studi). Di samping itu mahasiswa juga bisa mencetak hasil transkrip nilai. Semua data - data tersebut dapat dilihat oleh mahasiswa melalui situs sistem informasi akademik Politeknik Gorontalo [3]

Setelah Penulis amati, dari penelitian sebelumnya bahwa Sistem Akademik Politeknik Gorontalo khususnya di Monitoring perkuliahan masih mempunyai kekurangan yaitu, belum dapat menginputkan nilai sesuai dengan kriteria penilaian dosen masing - masing, dan nilai yang diinputkan belum sesuai dengan format penilaian dari Akademik.

Sehingga penulis akan mengembangkan sistem akademik tersebut, dengan cara dosen bisa menilai sesuai dengan kriteria masing - masing, dan penilain dosen akan di konfersi sesuai dengan penilain Akademik.

Dari uraian diatas maka penulis mengambil judul penelitian "SISTEM INFORMASI AKADEMIK KARTU HASIL STUDI BERBASIS WEB" di Kampus Politeknik Gorontalo.

\section{METODE PENELITIAN}

Gambaran umum sistem yang berjalan pada Sistem Informasi Akademik Kartu Hasil Studi Berbasis Web.

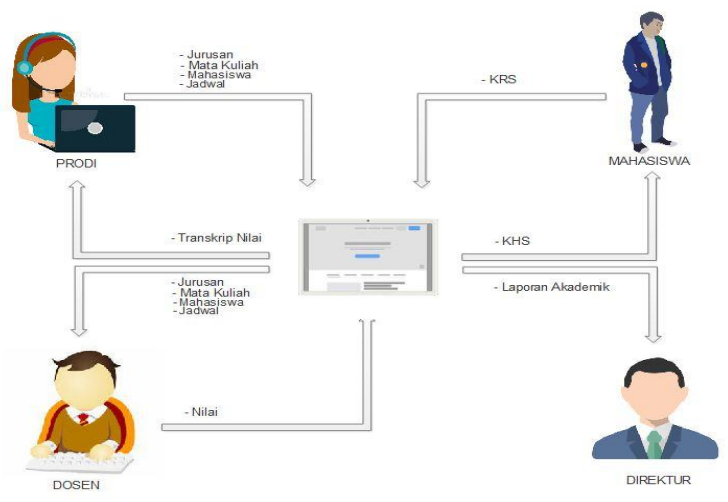

Gambar 1. Alur Sistem

Gambar 1 menjelasakan gambaran umum sistem yang berjalan pada laporan keuangan berbasis web berikut penjelasannya :

1. Prodi, Data yang akan diolah dalam penelitian ini adalah data Jurusan, Mata Kuliah, Mahasiswa, Jadwal. Data yang akan diproses untuk menjadi Transkrip nilai.

2. Mahasiswa, Data yang yang di inputkan dari mahasiswa adalah data KRS (Kartu Rencana Studi). Kemudian 
sistem yang akan mengolah data menjadi KHS (Kartu Hasil Studi).

3. Dosen mendapatkan data dari system, yaitu data Jurusan, Mahasiswa, Mata Kuliah, Jadwal. Data tersebut yang nantinya akan digunakan untuk melakukan proses pembelajaran, yang hasilnya nanti adalah daftar nilai dari masing - masing dosen.

4. Direktur mendapatkan Laporan Akademik dari sistem.

2.1. Bagan Alir Sistem Yang Diusulkan
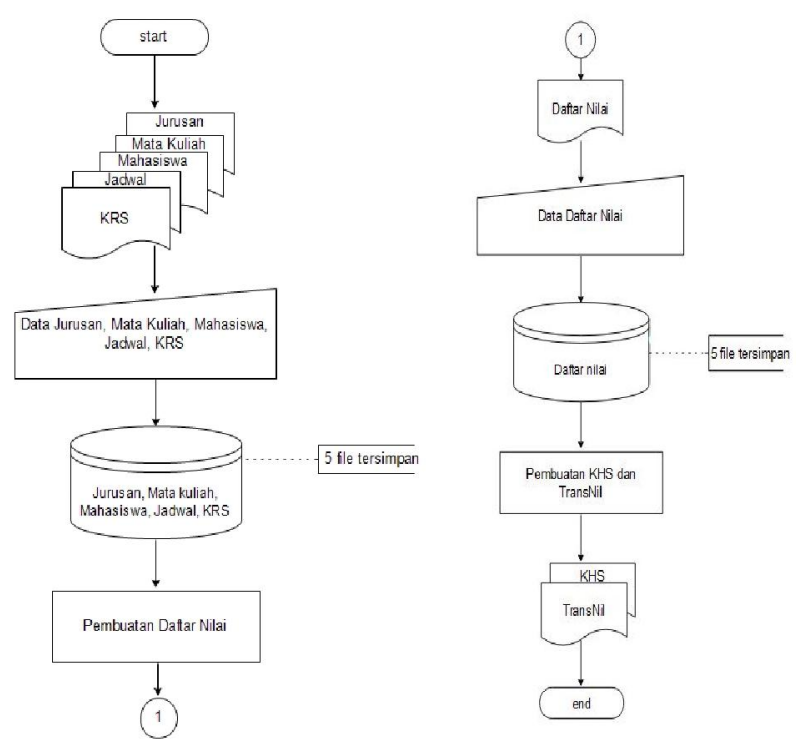

Gambar 2. Bagan Alir yang di Usulkan

2.2. Diagram Context

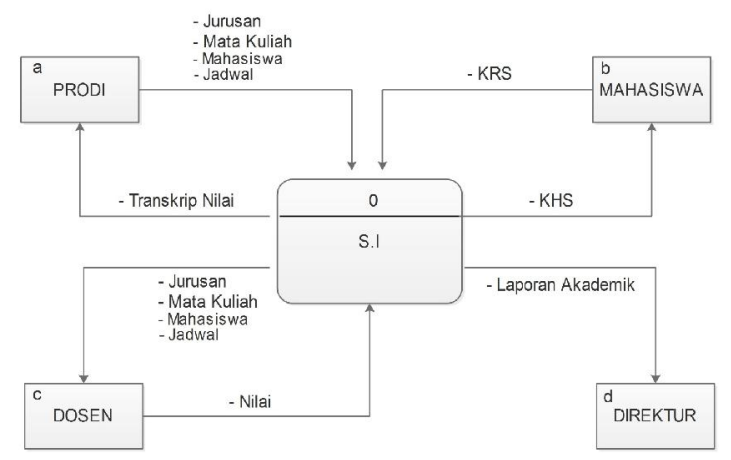

Gambar 3. Diagram Context

Digram context adalah diagram yang terdiri dari suatu proses yang menggambarkan ruang lingkup suatu sistem. Diagram konteks tertinggi dari DFD yaitu seluruh input ke sistem atau output dari sistem. Dalam diagram konteks hanya ada satu proses dan tidak boleh ada store dalam diagram konteks.

\subsection{Diagram Flow Data (DFD)}

Data Flow Diagram (DFD) merupakan suatu cara atau metode untuk membuat rancangan sebuah sistem yang mana berorientasi pada alur data yang bergerak pada sebuah sistem nantinya.

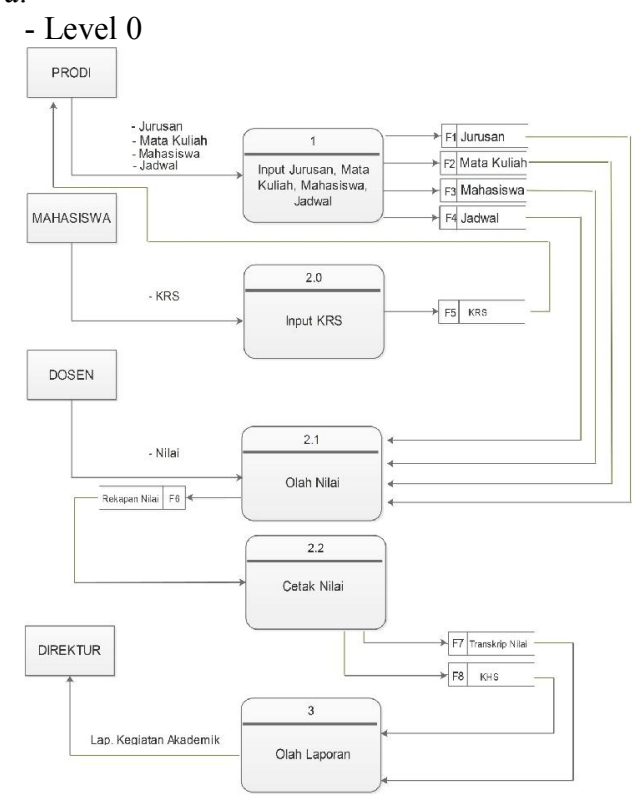

Gambar 4. DFD

- DFD Level 1 Proses 2

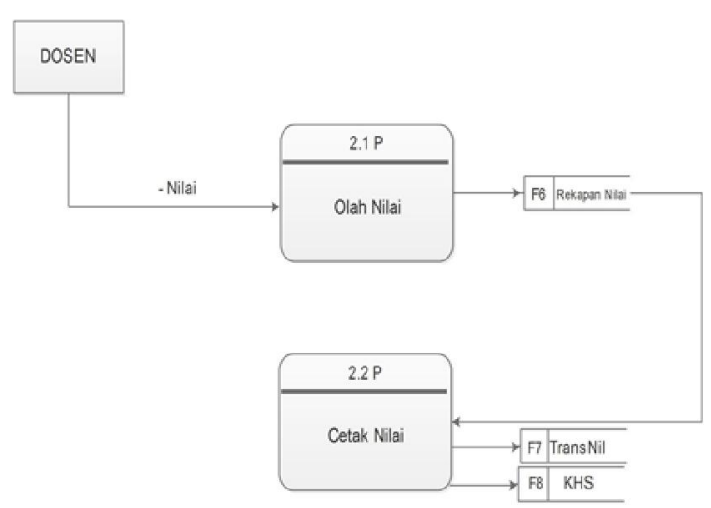

Gambar 5. Diagram Arus Data Level 1 Proses 2

\section{HASIL DAN PEMBAHASAN}

Aplikasi ini dirancang untuk memudahkan Dosen dalam mengelolah nilai dengan menggunakan aplikasi web. Setelah melalui proses analisis dan didesain secara rinci, maka akan menuju tahap implementasi. Implementasi merupakan tahap meletakan sistem siap untuk dioperasikan, sehingga pengguna dapat memberikan masukan kepada pembangunan sistem.

Pada pembuatan aplikasi web ini menggunakan framework codeigniter, framework codeigniter ini digunakan dengan konsep MVC (Models, Views, dan Controllers) 
dengan konsep MVC ini struktur folder lebih teratur. Berikut contoh susuna folder dengan konsep MVC :

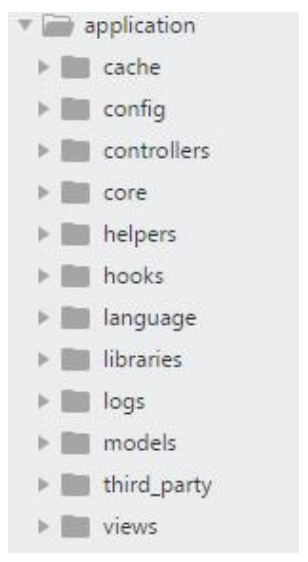

\subsection{Halaman Login Aplikasi}

Halaman ini, adalah menampilkan halaman login sistem, yaitu halaman dimana semua user melakukan proses login untuk dapat menggunakan Sistem Informasi Akademik Politeknik Gorontalo.

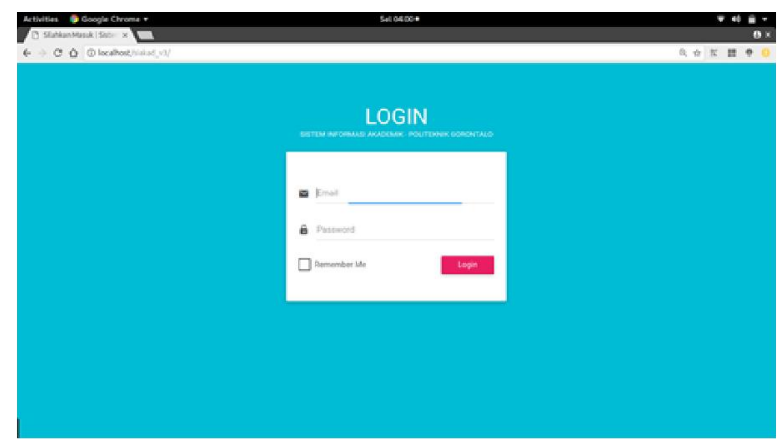

Gambar 6. Halaman Login

\subsection{Halaman Home Aplikasi}

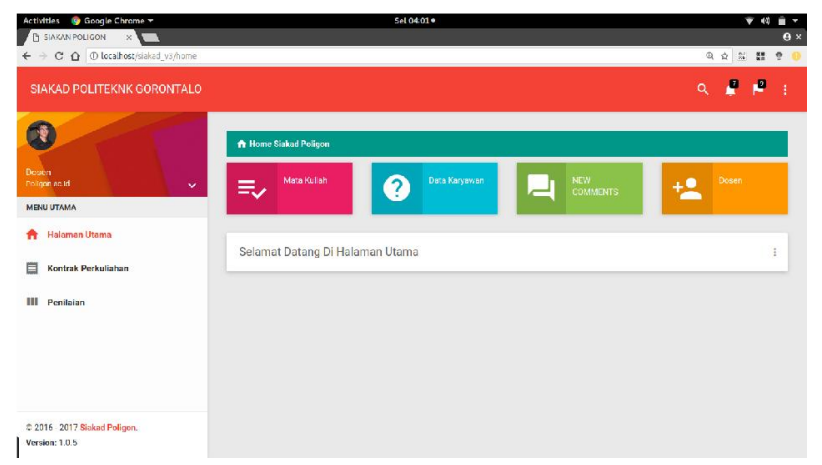

Gambar 7. Halaman Home Aplikasi

Halaman ini, adalah halaman depan Aplikasi setelah user berhasil login, pada halaman ini berisi tentang informasi Matakuliah, data karyawan, New Comments dan dosen. Halaman depan ini bertujuan untuk mengakses Sistem
Informasi Akademik Kartu Hasil Studi di Politeknik Gorontalo.

\subsection{Halaman Kontrak Perkuliahan}

Dihalaman ini Dosen akan membuat kontrak penilaian sesuai dengan matakuliah dan kelas yang di ampu. Isi dari halaman ini adalah dosen dapat membuat kontrak penilaian sesuai dengan matakuliah, yaitu dengan cara menginputkan kehadiran, tugas, quis, UTS dan UAS.

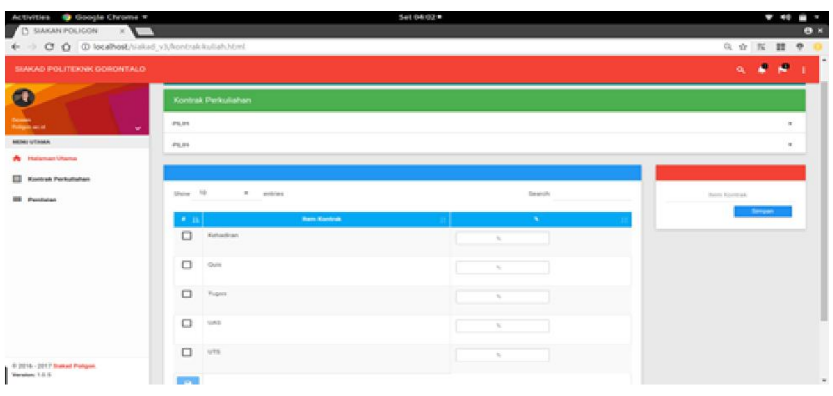

Gambar 8. Halaman Kontrak Perkuliahan

\subsection{Halaman Penginputan Nilai}

Halaman ini untuk menginputkan nilai sesuai dengan kontrak perkuliahan. Isi pada halaman ini yaitu untuk mengisi tanggal saat mengolah nilai.

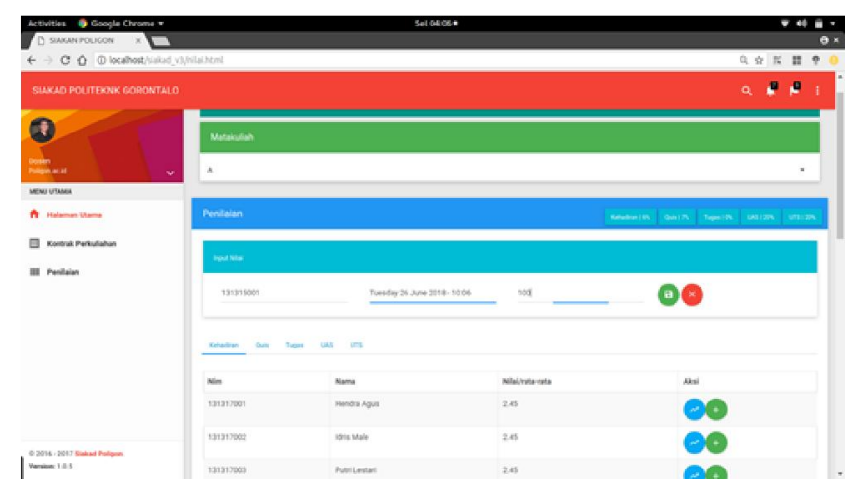

Gambar 9. Halaman Penginputan Nilai

\subsection{Halaman Daftar Nilai}

Dihalaman ini akan menampilkan daftar nilai sesuai Mahasiswa dan Kontrak Perkuliahan. Isi dari halaman ini pertemuan, tanggal pertemuan dan nilai. Sehingga tujuan dari daftar nilai ini akan menampilkan nilai mahasiswa sesuai kontrak perkuliahan. 


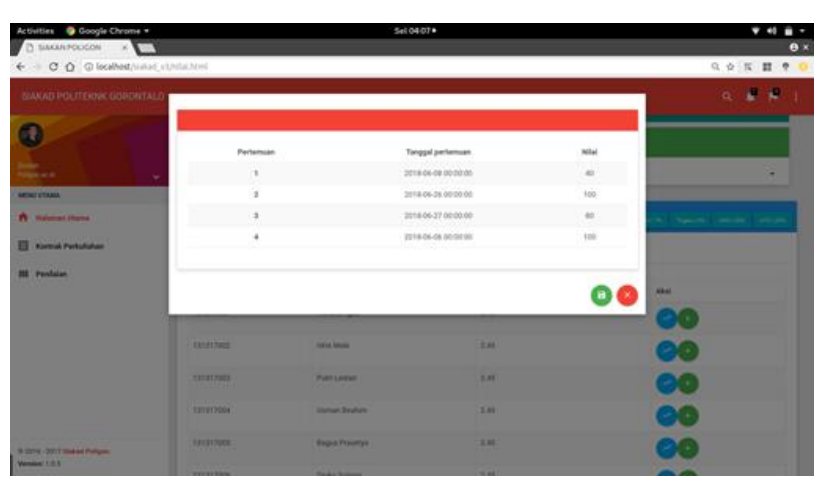

Gambar 10. Hamalan Daftar Nilai

\begin{abstract}
IV. PENUTUP
Kesimpulan

Dengan adanya aplikasi ini maka setiap mahasiswa Politeknik Gorontalo yang sudah mengikuti pelajaran dan sudah mendapatkan hasil nilai akhir dari semester yang sudah di tempuh, dapat melihat laporan berupa Kartu Hasil Studi dan Transkrip nilai dengan mengakses aplikasi yang sudah dibuat. Dengan demikian mahasiswa dapat mengetahui hasil nilai akhir selama semester yang dijalani. Tidak hanya mahasiswa, bagian akademik dapat melihat Kartu Hasil Studi mahasiswa dari berbagai jurusan yang ada di Politeknik Gorontalo.
\end{abstract}

\section{Saran}

Aplikasi ini masih dapat dikembangkan lagi, dengan membuat versi androidnya, dan di bagian Kartu Hasil Studi masih bias dikembangkan dengan membuat QR-CODE dibagian Kartu Hasil Studi.

\section{DAFTAR PUSTAKA}

[1] Alexander F. K. Sibero, 2011, Kitab Suci Web Programing, MediaKom, Yogyakarta.

[2] Andi dan MADCOMS. 2011. Aplikasi Web Database dengan Dreamweaver dan PHPMYSQL. Yogyakarta ; Andi.

[3] Husin, E. (2016). Sistem Informasi Akademik Monitoring Perkuliahan Berbasis Web Di Politeknik Gorontalo.

[4] Johnson, E. B. 2009. Contextual teaching and learning: menjadikan kegiatan belajar mengajar mengasyikkan dan bermakna. Bandung: Mizan Learning Center.

[4] Komputer, W. 2011. Kupas Tuntas Bermacam Aplikasi Generasi Cloud Computing. Yogyakarta: Penerbit ANDI.

[5] Ramadhan, A. (2008). Pembangunan Framework Sederhana untuk Aplikasi Sistem Informasi Sekolah.

[6] Riyanto, A. 2011. Aplikasi Metodologi Penelitian Kesehatan. Nuha Medika. Yogyakarta.
[7] Said, F. El. 2010. Sistem Basis Data-Entity Relatonship(ERD).

[8] Saputra, A, 2013. Membangun Aplikasi bioskop dan sms untuk panduan skripsi, Penerbit : PT Elex Media Komputindo , Jakarta.

[9] Wiharto, Y. 2011. SISTEM INFORMASI AKADEMIK BERBASIS SMS GATEWAY (studi kasus : Politeknik PalComTech Palembang) , Jurnal Politeknik PalComTech Palembang. 